\title{
İnformasiya təhlükəsizliyi üzrə aparılan tədqiqatların bibliometrik analizi (2007-2016-c1 illər)
}

\author{
Ramiz Alıquliyev ${ }^{1}$, Nərmin Adıgözəlova ${ }^{2}$ \\ 1,2 AMEA İnformasiya Texnologiyaları İnstitutu, Bakı, Azərbaycan \\ ${ }^{1}$ r.aliguliyev@gmail.com, ${ }^{2}$ narmin66@gmail.com
}

\begin{abstract}
Xülasə- Hazırda informasiya təhlükəsizliyi kompüter elmləri sahəsində aktual elmi istiqamətlərdən biridir. Məqalədə Web of Science elmi bazasında indeksləşən informasiya təhlükəsizliyi sahəsindəki əsərlərin bibliometrik analizi aparılmıșdır. Analiz nəticələri göstərir ki, bu sahədə çap olunan əsərlərin və istinadların sayında, eləcə do, jurnalların İF qiymətlərində artım müş̧ahidə olunur.
\end{abstract}

Açar sözlor- informasiya tohlükəsizliyi, şəbəko tohlükəsizliyi, bibliometrik analiz, Web of Science

\section{GIRIŞ}

Elmi tədqiqatçılar üçün tədqiqat sahəsinin inkişaf perspektivinin müəyyənləşdirilməsi mühüm amillərdən biridir. Buna görə də son zamanlar bir çox elmmetrik göstəricidən istifadə edərək tədqiqat sahəsinin inkişafını qiymətləndirmək mümkündür.

Kitabxana və informasiya elmi sahələri əsasən informasiyanın təsnifatlaşdırılması və təşkilini həyata keçirir. Son illər bir sıra göstəricilər əsasında əsərlərin bibliometrik analizi aparılır. Bunun nəticəsində də seçilmiş istiqamətin inkişafının müəyyən edilməsi mümkündür [1].

İndiyə kimi bir sıra tədqiqatçılar tərəfindən informasiya təhlükəsizliyinin bibliometrik analizi aparılmışdır [2]. Qeyd olunan işdə bibliometrik analizin aparılması üçün Scopus bazasının məlumatlarından istifadə olunmuşdur. $\mathrm{Bu}$ işdə isə bibliometrik analizin aparılması üçün Web of Science (WoS) elmi bazasının verilənlərindən istifadə olunur [3]. Bazada məlumatların əldə olunması üçün "Information Security", "Computer Security", "Mobile Security" və s. kimi açar sözlər vasitəsilə axtarış aparılmışdır.

\section{BİBLIOMETRIK ANALIZİIN NӘTICOLӘRİ}

Web of Science on böyük elmi bazalardan biridir [3]. Burada çox sayda elmi jurnallar, məqalələr, tezislər, kitablar, icmallar və $\mathrm{s}$. resurslar indeksləşir. $\mathrm{Bu}$ səbəbdən də araşdırmada WoS bazasından götürülmüş məlumatlardan istifadə olunmuş və nəticələrin müqayisəli təhlili aparılmışdır (01 noyabr 2017-ci il tarixə olan məlumatlar əsasında). Alınan nəticələr ölkələr, nəşrlər, istinadlara görə analiz edilmişdir.

WoS bazasında 2007-2016-cı illər üçün "təhlükəsizlik" açar sözü üzrə 182454 sayda resurs olduğu aşkar edilmişdir.

$\mathrm{Bu}$ resursların illər üzrə statistikası Şəkil 1-də göstərilmişdir.

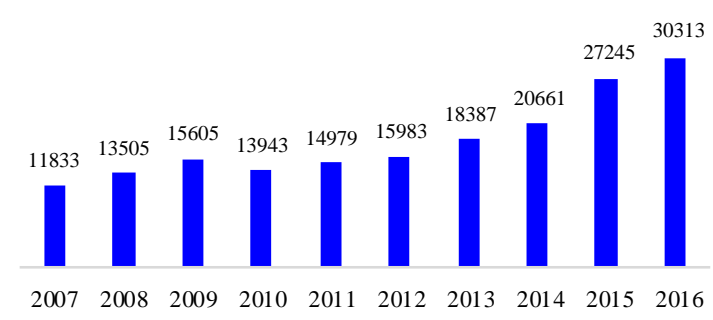

Şəkil 1. 2007-2016-c1 illərdə çap olunan əsərlərin statistikası

Şəkil 1-dən göründüyü kimi təhlükəsizlik üzrə çap olunan əsərlərdə 2009-cu ili nəzərə almasaq, digər illər ərzində artım dinamikası müşahidə olunur.

2007-2016-c1 illər ərzində çap olunan əsərlərin onların tipinə görə təsnifatı Şəkil 2-də verilmişdir.

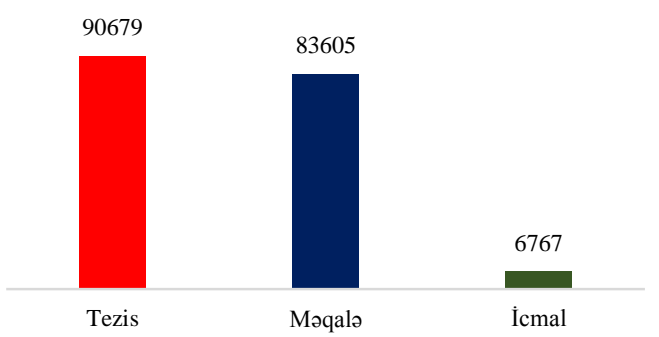

Şəkil 2. 2007-2016-c1 illər ərzində nəşr olunan əsərlərin sənədlərin tipinə görə təsnifat1

WoS bazasında "təhlükəsizlik" açar sözü ilə axtarış verdikdə ən çox tezis (90679) və məqalələrin (83605) olduğu nəzərə çarpır. Daha sonradan axtarışı dəqiqləşdirmək üçün 2007-2016-c1 illər ərzində "Information Security" və ya "Computer Security" və ya "Mobile Security" və ya "Network Security" və ya "Cyber Security" və ya "Cyberwarfare" və ya "Internet Security" açar sözləri ilə axtarıș dəqiqləşdirildi. Nəticə olaraq 16141 sayda resursun mövcud olduğu aşkarland.

Tapılan resursların müqayisəli analizindən göründüyü kimi bu istiqamətdə çap olunan tezislərin sayı məqalələrin sayından təqribən 2,5 dəfə çoxdur (Şəkil 3). 


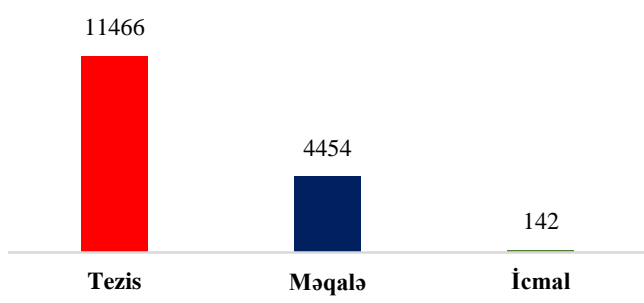

Şəkil 3. 2007-2016-c1 illər ərzində nəşr olunan əsərlərin sənədlərin tipinə görə təsnifat1

2007-2016-c1 illər ərzində çap olunmuş əsərləri təsnifatlandırdıqda 2007-ci ildən 2009-cu ilə qədər artım müşahidə olunur. 2010, 2011, 2012-ci illərdə 2009-cu ilə nisbətən azalma müşahidə olunsa da 2013-cü ildən sonra bu sahədə çap olunan əsərlərin sayında artım müşahidə olunur (Şəkil 4).

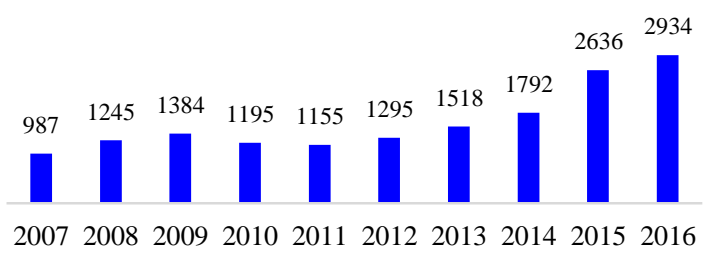

Şəkil 4. 2007-2016-cı illər ərzində nəşr olunan əsərlərin statistikası

Şəkil 5-də 2007-2016-c1 illərdə çap olunan əsərlərə olan istinadların illər üzrə statistikası əks olunmuşdur.

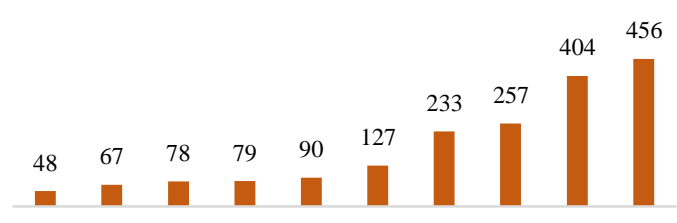

2007200820092010201120122013201420152016

Şəkil 5. 2007-2016-c1 illər ərzində istinadların statistikası

2007-ci ildə 987 sayda əsərə 48 dəfə istinad olunmuşdursa, 2016-c1 ildə 2934 sayda əsərə 456 dəfə istinad edilmişdir. Bu isə o deməkdir ki, 2007-ci ilə 1 əsərə orta hesabla 0.04 istinad düşürdüsə, 2016-c1 ildə bu göstərici 0.16-ya bərabər olmuşdur. Başqa sözlə, son on il ərzində bir əsərə düşən istinadların orta sayında 4 dəfə artım olmuşdur.

2007-ci ildən 2016-c1 ilə kimi informasiya təhlükəsizliyi üzrə çap olunan əsərlərin ölkələr üzrə paylanmasında ilk 5 yeri Çin (4495), ABŞ (3314), Hindistan (1198), Cənubi Koreya (653) və İngiltərə (645) bölüşdürür (Şəkil 6).

Onu da qeyd etmək olar ki, "Cyber Security" və ya "Cyberwarfare" sözləri ilə axtarış etdikdə digər açar sözlərə nisbətən daha az əsərin çap olunduğu və bu əsərlərin son illəri əhatə etdiyini müşahidə etmək olar.

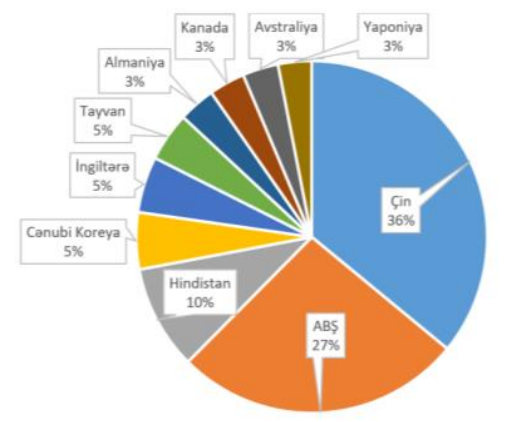

Şəkil 6. 2007-2016-cı illərdə informasiya təhlükəsizliyi üzrə əsərlərin ölkələr üzrə paylanması

Elmmetrik göstəricilərdən biri də bu sahədə çap olunan jurnallar hesab olunur. Jurnalın göstəriciləri dedikdə onların İmpakt Faktor (IF), SJR, SNIP və s. nəzərdə tutulur. Bunu nəzərə alaraq son illər təhlükəsizlik sahəsində çap olunan və WoS bazasında indekləşən ən yüksək İF-a malik olan 10 jurnal seçilmişdir (Cədvəl 1).

Cadvəl 1. WoS BAZASINDA İNDEKSLəŞəN JURNALLARIN SIYYHISI

\begin{tabular}{|c|c|c|c|c|c|c|c|c|}
\hline \multirow{2}{*}{ № } & \multirow{2}{*}{ Jurnalın adı } & \multicolumn{7}{|c|}{ İmpakt Faktor } \\
\hline & & 2010 & 2011 & 2012 & 2013 & 2014 & 2015 & 2016 \\
\hline 1. & $\begin{array}{l}\text { IEEE } \\
\text { Transactions on } \\
\text { Information } \\
\text { Forensics and } \\
\text { Security }\end{array}$ & 1.826 & 1.340 & 1.895 & 2.065 & 2.408 & 2.441 & 4.332 \\
\hline 2. & $\begin{array}{l}\text { International } \\
\text { Security }\end{array}$ & 3.444 & 2.333 & 2.739 & 2.975 & 3.868 & 3.275 & 3.390 \\
\hline 3. & $\begin{array}{l}\text { IEEE } \\
\text { Transactions on } \\
\text { Dependable } \\
\text { and Secure } \\
\text { Computing }\end{array}$ & 1.409 & 1.140 & 1.059 & 1.137 & 1.351 & 1.592 & 2.926 \\
\hline 4. & $\begin{array}{l}\text { Computers \& } \\
\text { Security }\end{array}$ & 0.889 & 0.868 & 1.158 & 1.172 & 1.031 & 1.640 & 2.849 \\
\hline 5. & $\begin{array}{l}\text { ACM } \\
\text { Transactions on } \\
\text { Information } \\
\text { and System } \\
\text { Security }\end{array}$ & 0.982 & 0.696 & 0.690 & 0.860 & 0.690 & 0.759 & 2.103 \\
\hline 6. & $\begin{array}{l}\text { International } \\
\text { Journal of } \\
\text { Information } \\
\text { Security }\end{array}$ & 1.094 & 0.421 & 0.480 & 0.941 & 0.963 & 1.279 & 1.915 \\
\hline 7. & $\begin{array}{l}\text { IEEE Security } \\
\text { \& Privacy }\end{array}$ & 0.791 & 0.898 & 0.962 & 0.721 & 0.731 & 0.902 & 1.382 \\
\hline 8. & $\begin{array}{l}\text { Security and } \\
\text { Communication } \\
\text { Networks }\end{array}$ & 0.356 & 0.414 & 0.311 & 0.433 & 0.72 & 0.806 & 1.067 \\
\hline 9. & $\begin{array}{l}\text { IET } \\
\text { Information } \\
\text { Security }\end{array}$ & 0.862 & 0.143 & 0.623 & 0.631 & 0.753 & 1.013 & 1.037 \\
\hline 10. & $\begin{array}{l}\text { Security } \\
\text { Journal }\end{array}$ & 0.583 & 0.605 & 0.341 & 0.455 & 0.628 & 0.867 & 0.978 \\
\hline
\end{tabular}

Cədvəl 1-də 2010-2016-c1 illərdə jurnalların İF qiymətləri göstərilmişdir. Şəkil 7-dən göründüyü kimi, 2010-2016-c1 illərdə təhlükəsizlik üzrə çap olunan jurnalların İF-da artım müşahidə olunur. Məsələn, 2010-cu ildə ən aşağ1 İF göstəricisi olan jurnal Security and Communication Networks (0.356) və on yüksək olanı International Security (3.444) jurnalı idisə, artıq 2016-c1 ildə ən aşağı İF göstəricisi olan Security Journal (0.978) və ən yüksək olanı isə IEEE Transactions on Information Forensics and Security (4.332) jurnalıdır. 


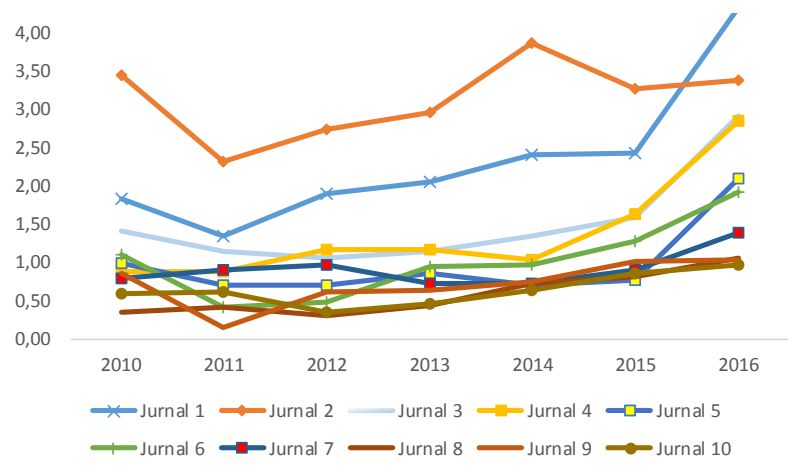

Şəkil 7. 2010-2016-cı illərdə jurnalların IF dinamikası

\section{MINNOTDARLIQ}

$\mathrm{Bu}$ iş Azərbaycan Respublikasının Prezidenti yanında Elmin inkişafı Fondunun maliyyə yardımı ilə yerinə yetirilmişdir - Qrant № EİF-2014-9(24)-KEPTL-14/02/1

\section{NӘTİCӘ}

Tezisdə 2007-2016-c1 illər ərzində informasiya təhlükəsizliyi sahəsində dərc olunan elmi əsərlərin və istinadların dinamikası analiz olunmuşdur. Analizin nəticələri göstərmişdir ki, həm elmi əsərlərin sayında, həm də istinadların sayında artım müşahidə olunur. $\mathrm{Bu}$ isə onu göstərir ki, informasiya təhlükəsizliyi kompüter elmləri sahəsində aktual elmi istiqamətlərdən biridir və bu tendensiya artmaqda davam edir. O cümlədən, inkişaf dinamikası bu istiqamətdə çap olunan jurnalların İF-nun artımında da müşahidə olunur.

\section{ӘDӘBIYYAT}

[1] C. Lu, W. Jen, W. Chang "Trends in computer crime and cybercrime research during the period 1974-2006: A bibliometric approach", Proceed. of Pacific Asia Workshop on Intelligence and Security Informatics (PAISI 2007), pp. 244-250, 2007.

[2] N. Ismayilova, "Biblometric analysis of information security", İnformasiya təhlükəsizliyinin multidissiplinar problemləri üzrə II respublika elmi-praktiki konfransının materialları, 2015, pp. 106-109.

[3] www.webofknowledge.com

\section{BIBLIOMETRIC ANALYSIS OF INFORMATION SECURITY} RESEARCH (2007-2016)

\footnotetext{
Ramiz Aliguliyev ${ }^{1}$, Narmin Adigozalova ${ }^{2}$

${ }^{1,2}$ Institute of Information Technology of ANAS, Baku, Azerbaijan ${ }^{1}$ r.aliguliyev@gmail.com, ${ }^{2}$ narmin66@gmail.com
}

Abstract - Currently information security is one of the topical issues in the field of computer science. Article analyzes bibliometric analysis of works in the field of information security indexed in Web of Science. The analysis shows that there is an increase in the number of publications and references published in this field, as well as the journal's IF prices.

Keywords - information security, network security, bibliometric analysis, Web of Science 